\title{
William Eagle Clarke, I.S.O., LL.D.
}

To the study of the vertebrate fauna of Scotland, and particularly of its birds, Dr Eagle Clarke made many contributions. That was an interesting development for a youth, born in Leeds in 1853 , who had been trained as a civil engineer, and it was partly due to an inherent love of nature and partly to the influence of a great teacher of zoology, Professor L. C. Miall, under whom Eagle Clarke studied at the Yorkshire College, which became the University of Leeds.

A definite trend was given to his life's work when at the age of thirty-one he was appointed Curator of the Leeds (Philosophical Society's) Museum, and its direction was fixed when four years later, in I888, he was made Assistant in the Natural History Department of the Museum of Science and Art (now the Royal Scottish Museum) in Edinburgh, under its first independent Keeper, Dr Ramsay H. Traquair. The great part of his working life was spent in that institution, where he succeeded Dr Traquair as Keeper in 1906, and from which he retired in I92I. There he made many changes, developing the collections for the use of students, encouraging the popular aspect of the exhibits, and bringing together by the way one of the finest exhibited collections and cabinets of British birds in the country.

Dr Clarke's scientific work covered a wide field in systematic zoology, ranging through all the classes of vertebrates, as witness his papers on the fishes of the Forth and its tributaries or his description of new forms of small mammals from the islands. But his name will be linked particularly with the study of birds, and there especially with the phenomena of migration. He added, perhaps more than any other, to the list of those rare birds which make an occasional appearance in Scotland. In Europe he found fresh material for publication in tracking the birds of Brabant, of Slavonia and Hungary, of Iceland and the Faroes, of the Pyrenees and the delta of the Rhône. Still further afield he identified collections of birds from the northern islands of Jan Mayen and Franz Josef Land, from Hudson's Bay, from the tropical Philippines, and from the Antarctic voyage of the Scotia.

His contributions to our knowledge of the migrations of birds are outstanding. Appointed a Member of the British Association Bird Migration Committee in 1880 , he drew up its final Reports, and in the 
course of collecting information he developed two effective methods of studying migration. By living in lighthouses and lightships and by enlisting the services of light-keepers he was able to catch bird movements in full swing, and his repeated visits during seasons of migration to Fair Isle, isolated between the Orkney and Shetland Islands, gave that tiny island something of the bird-watching fame which Gätke's fifty years of observation gave to Heligoland. The results of his observations appeared in final form in two volumes, Studies in Bird Migration (I9I2).

In addition to these volumes he published, with W. D. Roebuck, $A$ Handbook of Yorkshire Vertebrata (I88I); with J. G. Bartholomew and Percy H. Grimshaw an Atlas of Zoogeography (I9II); edited Colonel Wardlaw Ramsay's posthumous Birds of Europe and North Africa (1923); and rewrote Howard Saunders' Manual of British Birds (1927).

For forty years he acted as editor or as joint-editor of The Scottish Naturalist and its predecessor The Annals of Scottish Natural History, and in that capacity he guided to a great extent the development of field natural history in Scotland.

Dr Clarke's work gained him many marks of recognition. He was created a Member of the Imperial Service Order in 1920; the University of St Andrews conferred on him the degree of LL.D.; in I9I 8 he was elected President of the British Ornithological Union, and in 1922 he was made the first recipient of the Godwin-Salvin Medal. He was an honorary member of many foreign ornithological societies, and in this country he took part in several commissions concerned with wild birds and their protection, a subject upon which he acted as adviser to the Scottish Office for many years in connection with the administration of the Wild Birds Protection Acts.

Dr Clarke's holiday pursuits were angling and walking, and it was a great pleasure to share an outing with an observer so skilled and so well versed in field natural history. That was a study he did much to stimulate in Scotland, and many owe their interest in Scottish animals to his enthusiasm and kindly encouragement. He died, after a long period of failing health, on May IO, 1938, in his eighty-sixth year.

He was elected a Fellow of this Society in 1903.

J. R. 